Original Article

\title{
Pengaruh Aktivitas Fisik Jalan Kaki terhadap Kadar Gula Darah pada Pasien Diabetes Melitus di Wilayah Kerja Puskesmas Cianjur Kota
}

\author{
Egi Permana ${ }^{1}$, Siti Kamillah ${ }^{2}$, Khrisna Wisnusakti ${ }^{3}$ \\ ${ }_{1,2,3}$ Departemen Keperawatan, Sekolah Tinggi Ilmu Kesehatan Indonesia Maju \\ Jln. Harapan Nomor 50, Lenteng Agung, Jakarta Selatan 12610, Telp : (021)78894045 \\ Email : permanaegi07@gmail.com ${ }^{1}$
}

\begin{abstract}
Introduction: Diabetes mellitus (DM) is a chronic disease that occurs because the pancreas cannot produce enough insulin or the body cannot effectively use the insulin produced by the pancreas. There are 4 ways to maintain blood glucose levels, namely; pharmacological therapy, nutritional therapy, diabetes self management education, and physical activity. Walking exercise is the most often described as the modalities of physical activity to improve health.

Objective: The research objective was to determine the effect of walking physical activity on blood sugar levels in diabetes mellitus patients in the work area of the Cianjur Kota Health Center in 2021.

Method: This study used a design quasi-experimental with an approach one-group pretest-posttest design. The population of this study was all 620 people with diabetes mellitus who were taken using a simple random sampling technique, which was 17 respondents.

Results: Analysis of data using test paired sample t-test. Statistical test results obtained a p-value of $0.000<0.05$ so that Ha is accepted, which means there is an effect of physical activity on foot on blood sugar levels in diabetes mellitus patients in the work area of the Cianjur Kota Health Center in 2021.

Conclusion: This study found that walking exercise as far as 2,5 km for 30 minutes can lower blood sugar levels significantly in patients with diabetes mellitus.
\end{abstract}

Keywords: diabetes mellitus, blood sugar levels, physical activity on foot

Editor: $\mathrm{Yt}$

Hak Cipta:

(C2021 Artikel ini memiliki akses terbuka dan dapat didistribusikan berdasarkan ketentuan Lisensi Atribusi Creative Commons, yang memungkinkan penggunaan, distribusi, dan reproduksi yang tidak dibatasi dalam media apa pun, asalkan nama penulis dan sumber asli disertakan. Karya ini dilisensikan di bawah Lisensi Creative Commons Attribution Share Alike 4.0 Internasional. 


\section{Pendahuluan}

Penyakit tidak menular telah menjadi masalah kesehatan masyarakat yang tidak dapat dihindari. ${ }^{1}$ Salah satu Penyakit Tidak Menular (PTM) yang banyak mendapat perhatian adalah penyakit Diabetes Melitus. ${ }^{1}$ Diabetes merupakan penyakit yang jumlah penderitanya terus meningkat dari tahun ke tahun dan di Indonesia merupakan ancaman serius bagi pembangunan kesehatan nasional. ${ }^{1}$

Tercatat dalam International Diabetes Federation (IDF) bahwa di seluruh dunia terdapat sekitar 425 juta orang atau sekitar $8,8 \%$ orang diperkirakan menderita diabetes melitus. ${ }^{1}$ Jika hal ini terus berlanjut, diperkirakan pada tahun 2045 penderita diabetes melitus akan meningkat menjadi 629 juta orang di seluruh dunia. Jumlah penderita diabetes melitus di Asia Tenggara pada tahun 2017 sebanyak 159 juta orang dan diproyeksikan meningkat sebesar $15 \%$ atau sekitar 183 juta orang pada tahun $2045 .{ }^{1}$ Indonesia mencatatkan 10.3 juta orang dengan diabetes mellitus pada tahun $2017 .{ }^{2}$ Pada 2017 IDF Atlas, Indonesia menduduki tempat ke-6 daripada 10 negara dengan jumlah penderita diabetes mellitus tertinggi. ${ }^{2}$ Pada tahun 2045 orang dengan diabetes mellitus di Indonesia diperkirakan masih berada di 10 negara dengan diabetes mellitus tertinggi dan Indonesia berada di tempat ketujuh dengan 16.7 juta orang dengan diabetes mellitus dalam lingkungan usia 20 hingga 79 tahun. ${ }^{2}$ Prevalensi diabetes mellitus di Indonesia hasil Riskesdas 2018 meningkat menjadi 2.0\% untuk umur $\geq 15$ tahun dari 1,5\% pada Riskesdas 2018 Jawa Barat masih tinggi pada posisi 3 di Indonesia dibawah Jawa Timur 113.045 orang diikuti Jawa Timur 96.794 orang dan Sumatera Barat 36.410 orang berada pada posisi 4 setelah Jawa Barat dengan 131.846 orang. ${ }^{3}$ Di Jawa Barat sendiri, penyebaran diabetes mellitus masih tersebar di berbagai wilayah, salah satunya di Kabupaten Cianjur, ini dapat dilihat dari data Kantor Kesehatan Cianjur yang mempunyai prevalensi 3.495 orang dan diabetes mellitus yang meninggal memiliki prevalensi 282 orang. Berdasarkan data Dinas Kesehatan Kabupaten Cianjur tahun 2019, penderita diabetes mellitus terbanyak berada di Puskesmas Cianjur Kota. ${ }^{3}$

Diabetes adalah penyakit yang disebabkan oleh gangguan penyerapan gula darah oleh tubuh, sehingga membuat kadarnya dalam darah tinggi. Kadar gula darah yang tinggi inilah yang menyebabkan diabetes dan pada gilirannya menyebabkan berbagai komplikasi kesehatan lainnya. Diabetes adalah penyakit yang timbul akibat kadar gula darah yang tinggi (hiperglikemia). ${ }^{4}$

Menurut Helmawati (2014) secara umum pengendalian kadar gula darah tinggi dapat dilakukan dengan dua cara, yaitu pengobatan dengan penggunaan agen glikemik oral (Oral Hypoglycemic Agents/OHA) dan terapi penurunan gula darah melalui penerapan pola hidup sehat dengan menerapkan pola hidup sehat. diet dan olahraga. pelatihan fisik yang tepat. ${ }^{2}$

Salah satu jenis olahraga yang dianjurkan bagi penderita diabetes mellitus adalah jalan kaki. ${ }^{5}$ Menurut American College of Sports Medicine (ACSM), jalan kaki merupakan salah satu bentuk aktivitas fisik yang direkomendasikan untuk aktivitas sehari-hari. ${ }^{6}$ Jika aktivitas jalan kaki dilakukan sesuai rekomendasi ACSM seperti berjalan tanpa alas kaki atau hanya dengan sol tipis, hal ini dapat membantu seseorang bertransisi dari gaya hidup tidak aktif ke gaya hidup aktif. ${ }^{6}$ Jalan kaki dengan frekuensi tertentu bahkan dapat menurunkan risiko penyakit metabolik seperti diabetes melitus (kencing manis). ${ }^{4}$ Berdasarkan uraian di atas maka peneliti tertarik untuk melakukan penelitian tentang Pengaruh Aktivitas Fisik Jalan Kaki terhadap Kadar Gula Darah pada Penderita Diabetes Mellitus di Wilayah Kerja Puskesmas Cianjur Kota. 


\section{Metode}

Desain penelitian ini adalah quasi eksperimental dalam bentuk one group pre-post test design. Penelitian ini dilakukan dengan pemberian perlakuan aktivitas fisik jalan kaki dengan perlakuan 3 kali dalam 1 minggu. Dalam penelitian ini terdapat dua variabel dependen aktivitas fisik jalan kaki dan variabel independen diabetes melitus.

Populasi target penelitian ini adalah seluruh pasien yang menderita penyakit diabetes mellitus yang berada di Wilayah Puskesmas Cianjur Kota, dan populasi dalam penelitian ini sebanyak 620 responden. Pengambilan sampel penelitian ini menggunakan Purposive Sampling. Peneliti menggunakan kriteria inklusi dan eksklusi untuk menentukan sampel yang akan digunakan. Pengumpulkan data responden menggunakan alat pengukur Glukosa Test dan lembar observasi yang berisi pengukuran kadar gula darah sebelum dan sesudah aktivitas fisik, lembar observasi yang berisi aktivitas fisik, dan karakteristik responden yang memuat umur, jenis kelamin, dan lama menderita Diabetes Mellitus. Data yang dikumpulkan dari penelitian ini akan disimpan dan diproses untuk pengujian statistik terkomputerisasi. Analisis univariat menyajikan data dalam bentuk tabel pada deskripsi deskriptif variabel penelitian, yaitu deskripsi pengukuran kadar gula darah sebelum dilakukan aktivitas fisik, dan deskripsi pengukuran kadar gula darah setelah aktivitas fisik. Analisis bivariat menggunakan uji t-sampel berpasangan untuk melihat pengaruh aktivitas fisik terhadap kadar gula darah pada penderita diabetes melitus. Dalam penelitian ini, peneliti lolos dalam menjalankan etical clearance sebelum melakukan penelitian dengan nomor: 158/Sket/Ka-Dept/RE/STIKIM/XII/2021.

\section{Hasil}

\section{Karakteristik responden berdasarkan usia, jenis kelamin, dan lama menderita DM.}

Karakteristik responden berdasarkan usia, jenis kelamin, dan lama menderita diabetes melitus, dalam penelitian ini menggunakan analisis deskriptif yang dapat dilihat dibawah ini.

Tabel 1. Distribusi data usia responden di Wilayah Kerja Puskesmas Cianjur Kota 2021 (n=17)

\begin{tabular}{ccc}
\hline Usia & Frekuensi & Persentase \% \\
\hline $42-51$ tahun & 5 & 29,4 \\
\hline $58-64$ tahun & 12 & 70,6 \\
\hline Total & $\mathbf{1 7}$ & $\mathbf{1 0 0 , 0}$ \\
\hline
\end{tabular}

Tabel 1 diatas menunjukkan karakteristik responden berdasarkan usia menunjukkan bahwa sebagian besar responden berusia 58-64 tahun yaitu sebanyak 12 orang $(70,6 \%)$, sedangkan paling sedikit adalah responden berusia 42-51 tahun yaitu sebanyak 5 orang $(29,4 \%)$.

Tabel 2. Distribusi jenis kelamin responden di Wilayah Kerja Puskesmas Cianjur Kota 2021 $(n=17)$

\begin{tabular}{ccc}
\hline Jenis Kelamin & Frekuensi & Persentase $\%$ \\
\hline Laki-laki & 10 & 58,8 \\
\hline Perempuan & 7 & 41,2 \\
\hline Total & $\mathbf{1 7}$ & $\mathbf{1 0 0 , 0}$ \\
\hline
\end{tabular}


Tabel 2 diatas menunjukkan karakteristik responden berdasarkan jenis kelamin menunjukkan bahwa sebagian besar responden berjenis kelamin perempuan yaitu sebanyak 10 orang $(58,8 \%)$, sedangkan paling sedikit adalah responden berjenis kelamin laki-laki yaitu sebanyak 7 orang $(41,2 \%)$.

Tabel 3. Distribusi lama menderita DM responden di Wilayah Kerja Puskesmas Cianjur Kota $2021(n=17)$

\begin{tabular}{cccc}
\hline No & Lama Menderita DM & Frekuensi & Persentase \% \\
\hline 1 & 1 tahun & 2 & 11,8 \\
\hline 2 & 2 tahun & 4 & 23,5 \\
\hline 3 & 3 tahun & 1 & 5,9 \\
\hline 4 & 4 tahun & 3 & 17,6 \\
\hline 5 & 5 tahun & 2 & 11,8 \\
\hline 6 & 6 tahun & 2 & 11,8 \\
\hline 7 & 7 tahun & 1 & 5,9 \\
\hline Total & 8 tahun & 2 & 11,8 \\
\hline
\end{tabular}

Tabel 3 diatas menunjukkan karakteristik responden berdasarkan lama menderita DM diketahui sebagian besar responden menderita DM 2 tahun sebanyak 4 orang (23,5\%), sedangkan paling sedikit 3 dan 7 tahun sebanyak 1 orang $(5,9 \%)$.

\section{Analisa Univariat}

Tabel 4. Gambaran pengukuran kadar gula darah sebelum dilakukan aktivitas fisik di Wilayah Kerja Puskesmas Cianjur Kota 2021 (=17)

\begin{tabular}{cccc}
\hline Pengukuran & Mean & Min-Max & Std. Deviation \\
\hline Pre Test & 252,41 & $212-307$ & 31,470 \\
\hline Post Test & 246,06 & $205-301$ & 30,464 \\
\hline
\end{tabular}

Pada tabel 4 diatas menunjukkan bahwa kadar gula darah sebelum diberikan aktivitas fisik dengan jumlah 17 pasien yaitu kadar gula darah pasien diabetes melitus di Wilayah Kerja Puskesmas Cianjur Kota pada saat sebelum aktivitas fisik dengan nilai mean pre test $252 \mathrm{mg} / \mathrm{dl}$, nilai standard deviation (SD) pre test 31,470, dan nilai min-max pre test $212-307 \mathrm{mg} / \mathrm{dl}$. Disamping itu pula tabel 4 diatas menunjukkan bahwa kadar gula darah setelah aktivitas fisik berjumlah 17 pasien yaitu kadargula darah pasien diabetes mellitus di Wilayah Kerja Puskesmas Kota Cianjur setelah aktivitas fisik dengan nilai mean post test $246 \mathrm{mg} / \mathrm{dl}$, standar deviasi (SD) post tes 30.464, dan nilai tes min-max post 205-301 mg/dl. 


\section{Analisa Bivariate}

Tabel 6. Uji Paired Sample T Test Pre-Post Test dengan kadar gula darah di Wilayah Kerja Puskesmas Cianjur Kota

\begin{tabular}{ccccc}
\hline Pengukuran & Mean Pre Test & $\begin{array}{c}\text { Mean } \\
\text { Post Test }\end{array}$ & Ranke Mean & Sig. (2-tailed) \\
\hline Pre Test - Post Test & 252,41 & 246,06 & 6,35 & 0,000 \\
\hline
\end{tabular}

Tabel 6 diatas menunjukkan nilai rerata sebelum aktivitas fisik jalan kaki adalah 252,41 dan nilai rerata setelah aktivitas fisik jalan kaki adalah 246,06, oleh karena itu berdasarkan hasil nilai tersebut dapat disimpulkan bahwa pasien yang telah melakukan aktivitas fisik jalan kaki mengalami penurunan kadar gula dalam darah yaitu 6,35. Penelitian ini dianalisis menggunakan uji t berpasangan dengan derajat kepentingan $=0,05$. Setelah dilakukan uji statistik dengan bantuan SPSS diperoleh nilai $p=0,000$. Yang berarti nilai $p<(0,000<0,05)$ yang berarti $\mathrm{H} 0$ ditolak dan $\mathrm{H} 1$ diterima. Sehingga dapat diartikan bahwa terdapat pengaruh yang signifikan antara aktivitas fisik jalan kaki terhadap kadar gula darah pada penderita diabetes melitus di Wilayah Kerja Puskesmas Kota Cianjur.

\section{Pembahasan}

\section{Karakteristik responden berdasarkan usia, jenis kelamin, dan lama menderita DM}

Dari segi usia, tabel 1 menunjukkan bahwa mayoritas responden berusia 58-64 tahun sebanyak 12 orang (70,6\%), sedangkan yang paling sedikit adalah responden berusia 42-51 tahun, yaitu sebanyak 5 orang $(29,4 \%)$. Responden dalam penelitian ini didominasi oleh lansia yang berusia di atas 45 tahun. Dimana hal ini dikarenakan semakin bertambahnya usia seseorang maka akan terjadi penurunan fungsi vital tubuh salah satunya adalah fungsi kelenjar prankea yang berperan langsung dalam produksi insulin dan mempengaruhi kadar gula darah.

Hal ini sejalan dengan teori yang dikemukakan oleh Tandra (2008), bahwa faktor degeneratif yaitu penurunan fungsi tubuh yang terjadi pada usia 45 tahun dapat meningkatkan risiko diabetes mellitus dan intoleransi glukosa terutama kemampuan sel untuk melakukan metabolisme glukosa untuk produksi insulin. ${ }^{7} \mathrm{Hal}$ ini dikarenakan pasien kurang berolahraga yang menyebabkan aktivitas sel beta pankreas untuk memproduksi insulin menurun dan sensitivitas sel jaringan menurun sehingga tidak menerima insulin, sedangkan fungsi utama hormon insulin adalah menurunkan kadar glukosa secara alami. ${ }^{8}$

Hal ini juga sejalan dengan penelitian Damayanti (2015) usia diatas 30 tahun atau lebih terjadi perubahan anatomis, fisiologis dan biokimiawi. Setelah seseorang mencapai usia 30 tahun, maka kadar glukosa darah naik 1-2 mg\% setiap tahun selama puasa dan akan naik 6-13 mg\% dalam 2 jam setelah makan. ${ }^{9}$

Hasil penelitian Sari (2018), "Pengaruh jalan kaki terhadap kadar gula darah pada penderita diabetes mellitus" menunjukkan bahwa sejumlah responden 8 orang (70\%) berusia 45-59 tahun menunjukkan peningkatan risiko diabetes mellitus. dengan bertambahnya usia dikaitkan dengan terjadinya diabetes mellitus. penurunan fungsi fisiologis tubuh. ${ }^{7}$ Sehingga dalam penelitian ini sesuai dengan teori yang ada karena responden didominasi oleh responden yang berusia diatas 45 tahun. 
Ditinjau dari jenis kelamin, tabel 2 menunjukkan bahwa sebagian besar responden berjenis kelamin perempuan yaitu sebanyak 10 orang $(58,8 \%)$, sedangkan paling sedikit responden adalah berjenis kelamin laki-laki yaitu sebanyak 7 orang $(41,2 \%)$.

Hal ini sejalan dengan teori yang dikemukakan oleh Taylor (2010) bahwa penyebab utama banyak wanita dengan diabetes mellitus adalah karena penurunan hormon estrogen terutama pada saat menopause. ${ }^{6}$ Hormon estrogen dan progesteron memiliki kemampuan untuk meningkatkan respon insulin dalam darah. Saat menopause terjadi, respon terhadap insulin menurun karena rendahnya hormon estrogen dan progesteron. Faktor lain yang berpengaruh adalah indeks massa tubuh wanita yang seringkali tidak ideal sehingga dapat menurunkan sensitivitas respon insulin. Hal inilah yang membuat perempuan lebih berpeluang terkena diabetes mellitus dibandingkan laki-laki. ${ }^{10}$

Hal ini juga sejalan dengan penelitian Yulia Patma Desita (2019), wanita memiliki risiko tinggi terkena diabetes mellitus, hal ini disebabkan karena kurangnya olahraga atau aktivitas fisik dan stres yang dapat mengakibatkan kurangnya konsumsi energi yang dapat mengakibatkan kelebihan energi dalam bentuk lemak, yang dapat menyebabkan kelebihan energi dalam bentuk lemak. dalam jangka panjang akan menyebabkan obesitas yang erat kaitannya dengan diabetes melitus. Selain itu, wanita juga memiliki hormon estrogen dan progesteron yang dapat mempengaruhi respon insulin sehingga kadar glukosa darah pada wanita penderita diabetes mellitus tidak terkontrol. ${ }^{11}$

Hasil penelitian Uswatun (2017), "Hubungan Kesadaran Diri dengan Kadar Glukosa Darah pada Pasien Diabetes Mellitus di RS Penyakit Dalam Dipoli Jombang" menunjukkan bahwa sebagian besar responden adalah wanita yaitu 93 responden $(69,4 \%)$. ${ }^{8}$ Dalam penelitian ini peneliti setuju dengan teori yang ada karena jumlah responden di Wilayah Kerja Puskesmas Cianjur Kota, jumlah responden perempuan lebih banyak daripada jumlah responden laki-laki.

Ditinjau dari segi umur panjang menderita diabetes mellitus, tabel 3 menunjukkan bahwa responden yang paling tua menderita diabetes mellitus 2 tahun sebanyak 4 orang $(23,5 \%)$, sedangkan paling sedikit 3 dan 7 tahun sebanyak 1 orang $(5,9 \%)$. Hasil penelitian dari Tsalissavrina I (2018), "Hubungan antara terdiagnosis diabetes dan kadar glukosa darah dengan fungsi kognitif penderita diabetes di Jawa Timur" sebanyak 72 orang $(4,0 \%)$ dengan diabetes mellitus > 5 tahun, diabetes mellitus dapat menimbulkan komplikasi, baik akut maupun kronis. ${ }^{12}$

Menurut peneliti, menurunkan kadar glukosa darah pada penderita diabetes melitus sebelum aktivitas fisik berjalan karena pasien masih tergolong pasien diabetes melitus baru, pasien merasa takut dan sangat berhati-hati dalam mengontrol kadar gula darah agar tidak menimbulkan komplikasi.

\section{Analisa Univariat}

\section{Gambaran pengukuran kadar gula darah sebelum dilakukan aktivitas fisik di Wilayah Kerja Puskesmas Cianjur Kota.}

Pada tabel 5 menunjukkan bahwa kadar gula darah sebelum diberikan aktivitas fisik dengan jumlah 17 pasien yaitu kadar gula darah pasien diabetes melitus di Wilayah Kerja Puskesmas Cianjur Kota pada saat sebelum aktivitas fisik dengan nilai mean pre test $252 \mathrm{mg} / \mathrm{dl}$, nilai standard deviation (SD) pre test 31,470, dan nilai min-max pre test $212-307 \mathrm{mg} / \mathrm{dl}$. 
Apabila dilihat dari hasil diatas tingginya kadar gula darah dikarenakan kurang banyaknya melakukan aktivitas fisik (jalan kaki) yaitu sebanyak 10 responden $(58,8 \%$ ) hanya melakukan aktivitas fisik 2 kali dalam satu minggu karena responden kebanyakan melakukan kegiatan sehari-hari seperti menyapu dan mengepel lantai, setelah pekerjaan rumah selesai responden hanya tiduran dan duduk tidak melakukan tindakan aktivitas lainnya.

Hal ini sesuai dengan teori yang dikemukakan oleh Damayanti (2015) pada saat melakukan latihan jasmani kerja isulin menjadi lebih baik dan yang kurang optimal menjadi lebih baik lagi. Akan tetapi efek yang dihasilkan dari latihan jasmani setelah 2 x 24 jam hilang, oleh karena itu untuk memperoleh efek tersebut latihan jasmani perlu dilakukan 2 hari sekali atau seminggu 3 kali dengan rentang waktu minimal 15-30 menit per hari. ${ }^{4}$

Hal ini juga sesuai dengan teori yang dikemukakan oleh Muhammad (2016) berjalan kaki dapat bermanfaat mengurangi risiko orang yang terkena DM atau yang sudah terkena penyakit DM untuk menurunkan kadar gula darah bisa diimbangi dengan jalan kaki selama 3050 menit perhari, jalan kaki tidak hanya bermanfaat untuk penyembuhan penyakit DM dan membantu penderita penyakit gangguan pernafasan dan jantung, upaya dalam pengontrolan kadar gula darah pasien DM ini adalah rutinnya melakukan aktivitas fisik dalam kehidupan sehari-hari. ${ }^{4}$

Hal ini juga sesuai dengan teori yang dikemukakan oleh Widiya (2015) mengatakan bahwa jalan kaki dapat dikatakan olahraga apabila dilakukan secara berkelanjutan dan minimal dilakukan selama 30 menit. ${ }^{4}$ Peneliti juga berpendapat bahwa dengan berjalan kaki tidak hanya menggerakan otot ekstermitas bawah tetapi menggerakan otot ekstermitas atas.

\section{Gambaran pengukuran kadar gula darah sesudah dilakukan ativitas fisik di Wilayah Kerja Puskesmas Cianjur Kota}

Pada tabel 6 menunjukkan bahwa kadar gula darah sesudah diberikan aktivitas fisik dengan jumlah 17 pasien yaitu kadar gula darah pasien diabetes melitus di Wilayah Kerja Puskesmas Cianjur Kota pada saat sesudah aktivitas fisik dengan nilai mean post test 246 $\mathrm{mg} / \mathrm{dl}$, nilai standard deviation (SD) post test 30,464, dan nilai min-max post test 205-301 $\mathrm{mg} / \mathrm{dl}$.

Menurut peneliti, seluruh 17 responden mengalami penurunan kadar glukosa darah setelah dilakukan intervensi jalan kaki pada penderita diabetes melitus. Hal ini menunjukkan bahwa intervensi jalan kaki memiliki peran penting dalam pengendalian kadar glukosa darah pada pasien diabetes melitus. Efek dari dilakukannya intervensi jalan kaki adalah meningkatkan sensitivitas insulin sehingga kadar glukosa darah pada pasien dapat ditekan.

Secara teoritis intervensi jalan kaki merupakan penatalaksanaan non farmakologis pada pasien diabetes melitus, jika dilakukan secara menyeluruh maka kadar glukosa darah dapat terkontrol. ${ }^{13}$ Namun, pada kenyataannya jumlah glukosa meningkat selama interval pengobatan karena peneliti tidak mengetahui apa yang dimakan atau dilakukan responden. Kemungkinan besar pasien pada saat dilakukan intervensi tidak memperhatikan prosedur pada saat melakukannya dan responden tidak memperhatikan saran dari peneliti tentang apa yang tidak boleh dilakukan oleh responden selain itu bisa juga karena usia pasien, sehingga hasil yang didapat kurang optimal yaitu kadar gula darah terus meningkat. ${ }^{13}$

Berdasarkan penelitian yang telah dilakukan oleh Yurida dan Zaqyyah Huzaifah (2019) dengan judul "pengaruh jalan kaki terhadap kadar gula darah pada pasien diabetes mellitus tipe II". ${ }^{5}$ Hasil penelitian didapatkan rata-rata kadar gula darah responden sebelum melakukan jalan 
kaki sebesar 238,2 mg/dl sedangkan rata-rata kadar gula darah responden sesudah melakukan jalan kaki sebesar 203,4 mg/dl. Hasil uji statistik menunjukkan ada pengaruh jalan kaki terhadap kadar gula darah pasien diabetes mellitus tipe II. Hasil analisis uji statistik diperoleh nilai $\mathrm{p}=0,000$ maka dibawah nilai $\alpha=0,05(\mathrm{p}<0,05)$ dengan demikian secara statistik pada tingkat kepercayaan $95 \%$ ada pengaruh jalan kaki terhadap kadar gula darah pasien diabetes mellitus tipe II. ${ }^{5}$

Hasil penelitian ini sejalan dengan hasil penelitian yang dilakukan oleh Liwu (2016) yang menunjukkan ada pengaruh antara terapi jalan kaki terhadap penurunan kadar gula darah pada panderita diabetes mellitus tipe 2 di Desa Bajarbillah Tambelangan Kabupaten Sampang ( $\mathrm{p}$ value $=0,00)$. Hasil penelitian lainnya yaitu penelitian Isrofah (2015) menunjukkan ada pengaruh jalan kaki 30 menit terhadap nilai gula darah pada pasien diabetes mellitus tipe II di Desa Karangsari Kecamatan Karanganyar Kabupaten Pekalongan (p value = 0,018). ${ }^{6}$

Penurunan kadar gula darah dapat dikarenakan frekuensi melakukan aktivitas fisik dalam satu minggu. Berdasarkan hasil penelitian responden yang memiliki kadar gula darah tertinggi $182 \mathrm{mg} / \mathrm{dL}$ melakukan aktivitas fisik 2 x dalam satu minggu. ${ }^{4}$ Sehingga efek kerja insulin yang dihasilkan dari latihan jasmani hilang atau terjadi resistensi insulin. Sedangkan responden yang setelah melakukan senam diabetes memiliki kadar gula darah rendah $96 \mathrm{mg} / \mathrm{dL}$ melakukan aktivitas fisik setiap hari sehingga insulin bekerja optimal dengan mengaktifasi ikatan insulin dan reseptor insulin di membran plasma sehingga dapat menurunkan kadar glukosa darah. ${ }^{4}$

Penelitian yang dilakukan dapat dilihat faktor yang mempengaruhi penuruan kadar gula darah yaitu frekuensi melakukan aktivitas fisik (olahraga) dalam satu minggu. Selain itu penurunan kadar gula darah juga dipengaruhi beberapa faktor yang tidak diteliti, seperti tercapainya intensitas senam diabetes yang baik.

\section{Analisa Bivariat}

\section{pengaruh kadar gula darah pasien diabetes melitus di Wilayah Kerja Puskesmas Cianjur Kota sebelum dan sesudah dilakukan aktivitas fisik.}

Pada tabel 7 menunjukkan bahwa nilai mean sebelum dilakukan aktivitas fisik jalan kaki yaitu 252,41 dan nilai mean sesudah dilakukan aktivitas fisik jalan kaki yaitu 246,06, maka dilihat dari hasil nilai tersebut dapat disimpulkan bahwa pasien yang sudah dilakukan aktivitas fisik jalan kaki ada penurunan nilai kadar gula darah yaitu 6,35. Penelitian ini dianalisis menggunakan uji paired t-test dengan menggunakan derajat kemaknaan $\alpha=0.05$. Setelah dilakukan uji stastitik dengan bantuan SPSS diperoleh nilai $p$-value $=0.000$. Yang berarti $p$-value $<\alpha(0.000<0.05)$, artinya $\mathrm{H}_{0}$ di tolak dan $\mathrm{H}_{1}$ diterima. Maka dapat diartikan ada pengaruh yang signifikan antara aktivitas fisik jalan kaki terhadap kadar gula darah pada pasien diabetes melitus di Wilayah Kerja Puskesmas Cianjur Kota.

Para peneliti berpendapat bahwa efek berjalan pada perubahan kadar glukosa darah yang dapat mengontrol kadar gula darah pada penderita diabetes mellitus terkait erat dengan sistem pembakaran glukosa darah dalam sel melalui kinerja insulin. Sensitivitas insulin erat kaitannya dengan aktivitas olahraga, orang yang berolahraga memiliki kadar glukosa darah yang seimbang karena efektivitas insulin dalam mengubah glukosa menjadi energi.

Ini dibuktikan dari kajian sebelumnya yang dilakukan oleh Arkan Adi Widiya, 2015 "Kesan berjalan santai pada tahap glukosa darah pada pesakit diabetes mellitus" ada kesan berjalan kaki selama 30 menit dapat menurunkan kadar glukosa darah secara signifikan. ${ }^{4}$ 
Ini juga dibuktikan dari kajian sebelumnya yang dilakukan oleh Yusra, A. (2016) "Kesan Latihan Berjalan Terprogram terhadap Perubahan Tahap Glukosa Darah pada Penderita Diabetes Mellitus Jenis 2 di Kawasan Kerja Pusat Kesehatan Laut, Kabupaten Aceh Utara" ada pengaruh yang signifikan antara latihan berjalan perubahan perubahan tahap glukosa darah pada pesakit dengan diabetes mellitus jenis $2 .^{7}$

Ini juga dibuktikan dari kajian sebelumnya yang dilakukan oleh Ari Widiarto (2018), "pengaruh senam jalan cepat terhadap tekanan darah penderita hipertensi di desa sengon wilayah kerja puskesmas jabon" menyatakan bahwa senam jalan cepat dapat menurunkan tekanan darah pada penderita tekanan darah tinggi, olahraga juga dapat mengurangi pembentukan plak yang disebabkan oleh lemak dan glukosa dalam tubuh. ${ }^{15}$

Hal ini berbeda dengan penelitian yang dilakukan oleh Isrofah, Hurhayati, dan PA (2015) "Efektivitas Jalan Kaki 30 Menit Terhadap Nilai Gula Darah Pada Penderita Diabetes Mellitus Tipe II di Desa Karangsari Kabupaten Karanganyar Kabupaten Pekalongan” yang menyatakan bahwa Wilcoxon Hasil pengujian didapatkan 0,80>0,05 yang artinya tidak ada pengaruh jalan kaki selama 30 menit terhadap nilai gula darah pada penderita diabetes melitus Tipe II di Desa Karangsari Kabupaten Karanganyar Kabupaten Pekalongan. Responden yang mengalami penurunan kadar gula darah setelah berjalan kaki selama 30 menit sebanyak 7 orang $(35 \%){ }^{6}$

Keteraturan dalam melakukan aktivitas fisik paling besar pengaruhnya terhadap keberhasilan pengobatan diabetes melitus. Latihan fisik secara teratur merupakan bagian penting dari pengelolaan diabetes mellitus dalam kehidupan sehari-hari yang telah terbukti dapat menjaga berat badan, menjaga tekanan darah normal, membantu meningkatkan fungsi insulin dalam tubuh dan meningkatkan kesehatan psikologis. ${ }^{8}$

Jalan kaki memiliki peranan penting dalam pengaturan kadar glukosa darah, sedangkan manfaat beraktivitas fisik seperti jalan kaki pada penderita diabetes melitus mampu mengkontrol kadar glukosa dalam darah, mencegah kegemukan lipid darah dan peningkatan tekanan darah. ${ }^{9}$

\section{Kesimpulan}

Berdasarkan hasil penelitian yang telah dilakukan oleh peneliti mendapatkan kesimpulan bahwa nilai rata-rata kadar gula darah responden sebelum dilakukan intervensi 252,41 dan nilai rata-rata kadar gula darah responden setelah dilakukan intervensi didapatkan penurunan 246,06 sehingga dapat disimpulkan bahwa terdapat pengaruh aktivitas fisik jalan kaki terhadap kadar gula darah pada pasien diabetes melitus di wilayah kerja Puskesmas Cianjur Kota.

\section{Konflik Kepentingan}

Peneliti menyatakan bahwa penelitian ini independen dari konflik kepentingan individu dan organisasi.

\section{Ucapan Terima Kasih}

Terimakasih kepada seluruh pihak yang telah berkontribusi membantu proses penelitian ini.

\section{Pendanaan}

Sumber pendanaan diperoleh dari peneliti. 


\section{Daftar Pustaka}

1. Atlas D. International diabetes federation. IDF Diabetes Atlas, 7th in Brussels, Belgium Int Diabetes Fed. 2015;

2. Helmawati T. Hidup Sehat Tanpa Diabetes. 2014;

3. Maryati S, Jati SP, Wulan LRK. ANALISIS PROGRAM AUDIT MATERNAL-PERINATAL (AMP) DI KABUPATEN CIANJUR TAHUN 2012. J Kesehat Budi Luhur J Ilmu-Ilmu Kesehat Masyarakat, Keperawatan, dan Kebidanan. 2019;12(2):172-81.

4. Yurida Y, Huzaifah Z. Pengaruh Jalan Kaki Terhadap Kadar Gula Darah Pada Pasien Diabetes Mellitus Tipe II. Din Kesehat J KEBIDANAN DAN KEPERAWATAN. 2019;10(2):911-5.

5. Isrofah I, Nurhayati N, Angkasa P. Efektifitas Jalan Kaki 30 Menit Terhadap Nilai Gula Darah Pada Pasien Diabetes Mellitus Tipe II Di Desa Karangsari Kecamatan Karanganyar Kabupaten Pekalongan. J Holist Nurs Sci. 2017;4(1):16-24.

6. Colberg SR, Sigal RJ, Fernhall B, Regensteiner JG, Blissmer BJ, Rubin RR, et al. Exercise and type 2 diabetes: the American College of Sports Medicine and the American Diabetes Association: a joint position statement. Diabetes Care. 2010;33(12):e147-67.

7. Sari DM. Pengaruh Senam Diabetes Mellitus Terhadap Kadar Gula Darah Pada Penderita Diabetes Mellitus Tipe 2 (Di Dusun Candimulyo Desa Candimulyo Kecamatan Jombang Kabupaten Jombang). STIKes Insan Cendekia Medika Jombang; 2018.

8. Kasana RU, Suhariati HI, Siskaningrum A. Hubungan Antara Self Awareness Dengan Kadar Glukosa Darah Pada Pasien Dm Tipe 2 (Studi Di Poli Penyakit Dalam Rsud Jombang). Hosp Majapahit. 2019;11(1):11-6.

9. Damayanti S. Diabetes mellitus dan penatalaksanaan keperawatan. Yogyakarta Nuha Med. 2015;

10. Hongdiyanto A. Evaluasi kerasionalan pengobatan diabetes melitus tipe 2 pada pasien rawat inap di rsup prof. Dr. RD Kandou manado tahun 2013. PHARMACON. 2014;3(2).

11. Desita YP. Pengaruh Walking Exercise Terhadap Perubahan Kadar Glukosa Darah Pada Penderita Diabetes Mellitus Tipe 2 Dengan Pendekatan Theory Of Planned Behavior Di Desa Banjardowo Kabupaten Jombang. STIKes Insan Cendekia Medika Jombang; 2019.

12. Tsalissavrina I, Tritisari KP, Handayani D, Kusumastuty I, Ariestiningsih AD, Armetristi F. Hubungan lama terdiagnosa diabetes dan kadar glukosa darah dengan fungsi kognitif penderita diabetes tipe 2 di Jawa Timur. AcTion Aceh Nutr J. 2018;3(1):28-33.

13. Widiya AA. Pengaruh Olahraga Jalan Santai Terhadap Kadar Glukosa Darah Pada Pasien Diabetes Mellitus. Universitas Muhammadiyah Surakarta; 2015.

14. Yusra A. Pengaruh Walking Exercise Terprogram Terhadap Perubahan Kadar Glukosa Darah pada Penderita Diabetes Mellitus Tipe 2 di Wilayah Kerja Puskesmas Samudera Kabupaten Aceh Utara. 2016;

15. Widiarto A. Pengaruh Brisk Walking Excercise Terhadap Tekanan Darah Penderita Hipertensi di Desa Sengon, Wilayah Kerja Puskesmas Jabon. STIKes Insan Cendekia Medika Jombang; 2018.

16. Upton D. Introducing psychology for nurses and healthcare professionals. Routledge; 2013. 